\title{
O romance de Ricardo Lísias: janelas escancaradas para o sujeito hipermoderno
}

\author{
The novel by Ricardo Lísias: wide open windows to the subject hypermodern \\ Ana Cláudia Munari \\ Taíssi Alessandra Cardoso da Silva \\ Universidade de Santa Cruz do Sul - Santa Cruz do Sul - Rio Grande do Sul - Brasil
}

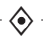

\begin{abstract}
Resumo: A partir da análise dos romances de Ricardo Lísias e da sua produção autocrítica, este trabalho busca entender algumas relações entre a literatura de autoficção e a publicização do sujeito autor imerso no universo midiático. Partindo de uma revisão bibliográfica que conceitua os objetos aqui circunscritos e de uma apreciação anterior sobre a produção literária de jovens escritores brasileiros selecionados pela revista Granta em 2012, estreitamos nossa focalização no movimento do romancista em direção à escrita de si e à autorreferência. Nesse sentido, analisamos e contextualizamos a modalidade de escritura denominada autoficção, especialmente no que tange às aproximações entre as instâncias do narrador e do autor e entre biografemas e ficção (FIGUEIREDO, 2013; KLINGER, 2012), e evocamos estudos da Sociologia e da Comunicação de modo a caracterizar a sociedade da qual emerge o corpus deste estudo (LIPOVESTKY, 2004; SANTAELLA, 2012). A partir desse contexto, investigamos as obras literárias - O céu dos suicidas (2012), Divórcio (2013) e Delegado Tobias (2014) - e as narrativas midiáticas de Ricardo Lísias e identificamos nelas estratégias da publicidade.
\end{abstract}

Palavras-chave: Autoficção; Literatura contemporânea; Hipermodernidade; Ricardo Lísias

\begin{abstract}
Through the analysis of the novels of Ricardo Lísias and its self-critical production, this work intends to understand some relationships between the self-fiction literature and the popularization of the subject author immersed in the media universe. Starting from a literature review that conceptualizes the objects herein bounded and an earlier assessment of the literary production of young Brazilian writers selected by Granta magazine in 2012, we strengthened our focus on the novelist's movement toward the writing itself and self-reference. Pursuing this aim, we analyzed and contextualized the form of writing named autofiction, especially with regard to the similarities between instances of the narrator and the author and between biographema and fiction (FIGUEIREDO, 2013; KLINGER, 2012). We also evoked Sociology and Media Studies to characterize the society of which emerges the corpus of this study (LIPOVESTKY, 2004; SANTAELLA, 2012). From these premises, we investigated the literary works - Céu dos suicidas (Heaven suicide, 2012), Divórcio (Divorce, 2013) and Delegado Tobias (Tobias, the police chief, 2014) - and the media narratives of Ricardo Lísias and finally we identified his advertising strategies.
\end{abstract}

Keywords: Self-ficction; Contemporary literature; Hypermodernity; Ricardo Lísias

As perguntas sobre o presente, a partir de várias esferas de pensamento, têm esbarrado justamente nas questões que são também respostas: o esboroamento de antigas molduras, a impossibilidade de erigir totalidades, a fragmentação dos discursos - e a própria noção dessa pluralidade -, a virtualidade das noções de tempo, presença e mesmo de sujeito. Para além do anacronismo, o interesse sobre essa ilusão que é o presente continua a mover olhares comparativos, entre o ontem e o hoje, advindos do campo das artes e da cultura - exercício que já rendeu muitos "ismos". Nas últimas três décadas, desde a Cultura das mídias (SANTAELLA, 1996), no entanto, o efeito das novas formas de produzir e distribuir conteúdo tem produzido certo silenciamento naqueles que se 
ocupam em entender diacronicamente esse universo: não há mais distância entre os fenômenos e sua transformação; não há margens entre os fenômenos ${ }^{1}$.

Nesse contexto, a literatura sofreu duplamente: porque tem relação com as mentalidades; e porque essas novas mentalidades têm sentido justamente em elementos que configuram os fenômenos literários: as mitologias (hibridizadas pela convergência midiática), a escrita (virtualizada pela imaterialidade da nuvem), a separação entre autor e leitor (extinta pela coincidência entre papéis). É nesse sentido que parecem retornar velhas contendas sobre o que é literatura ou o que identifica as literaturas nacionais - questões caras em tempos de ismos - e, ainda, sobre a qualidade do romanesco, gênero que nasceu justamente sob a égide de mudanças paradigmáticas, calcadas na própria noção de sujeito que ora se problematiza.

É justamente graças a essa sua qualidade razoavelmente plurivalente, no entanto, que podemos classificar obras esteticamente tão divergentes - ainda que igualmente contemporâneas - como Eles eram muitos cavalos (2000), de Luiz Ruffato, e Reprodução (2013), de Bernardo Carvalho, como romances, assim como o são Helena, de Machado de Assis, e Grande sertão: veredas, de Guimarães Rosa. E aqui cabe a pergunta deste tempo: que se tem passado com o romance - "a epopeia do mundo abandonado por Deus" (LUKÁCS, 2003, p. 89) - nessa era de convergência de culturas, linguagens, gêneros e sujeitos?

Sincronicamente, aqueles objetos que podem ser abarcados pelo gênero romance podem ser, dessa forma, bastante heterogêneos, em que pesem não apenas questões de estilo, mas também a interação com contextos, culturas e mesmo voz, focalização e relação com a realidade e, nesse sentido, poderíamos evocar ainda com bastante pertinência os estudos de Georg Lukács ( $A$ teoria do romance, 1916, 1920, 1962). Diacronicamente, podemos levar em conta também alguns desses critérios - como estilos e culturas - porém, mesmo esses elementos agem sob forças que advêm de movimentos para além do próprio exercício da escritura, guiado pelas molduras do romanesco, e que podemos colocar na esfera das mentalidades, como o "saber social" e a "atitude" (GUMBRECHT, 1996, p. 230).

Inserido neste movimento - talvez esquizofrênico como o presente -, este trabalho observa a obra de Ricardo Lísias justamente em um exercício que entrevê, nem a totalidade, nem o paradigma, sequer a comparação, mas, talvez, unicamente um exemplo de

\footnotetext{
A problemática da História da Literatura é mais antiga e mais ampla, e tem sido discutida, entre outros, por Maria Eunice Moreira, por exemplo, em "História da literatura: alguns problemas e (in)certas propostas", in: MOREIRA, Maria Eunice (Org.). Papéis nada avulsos. Porto Alegre: Edipucrs, 2012.
}

uma tendência, ancorada nas mentalidades que então discutimos, que tanto pode vir a ser quanto se liquefazer. Essa hipótese faz convergir, assim, a autoficção, como manifestação das "escritas de si" já tomadas como tendência do contemporâneo pelos autores aqui trazidos, e a autopublicização do autor, como formas de afirmação do sujeito que escreve, personagem desse mundo a que o romance, ainda, tenta trazer sentido.

A presença do escritor em seu texto é um fenômeno crescente na literatura contemporânea, em que a demarcação daquele que fala é intencionalmente ressaltada, de modo a localizá-lo no contexto a partir do qual escreve - quando a multiplicidade e o barulho das vozes apagam as idiossincrasias. Dalcastagnè (2012) acredita que essa é uma tendência da literatura na contemporaneidade, tanto no que diz respeito à esterilidade do exercício puramente narcisístico, quanto na exploração desse fenômeno como estratégia estética e discursiva. Nesse contexto, o autor torna-se o ponto central da narrativa contemporânea, sentindo-se como que impelido a "dizer-se" de alguma maneira, às vezes a partir de uma personagem que o espelha ou na introdução de biografemas (BARTHES, 1984, 2003, 2005), embaralhando verossimilhança e realidade. Dalcastagnè (2012, p. 106) considera essa uma atitude coerente com o momento hodierno, já que toma o escritor também como uma peça desse jogo: "Se os narradores estão confusos, as personagens desarticuladas e os leitores desconfiados, qual a situação do autor, cada dia mais pressionado entre as exigências do campo literário e as impossibilidades do mercado?". Klinger (2012) evidencia esse que é o traço mais saliente na ficção recente: a frequência do autobiografismo em narrativas que, sobretudo, são ficcionais.

Para Foucault (1994), o autor existe como função autor: um nome de autor não é simplesmente um elemento num discurso, mas ele exerce um certo papel em relação aos discursos, assegura uma função classificadora, manifesta o acontecimento de um certo conjunto de discursos e se refere ao estatuto deste discurso no interior de uma sociedade e no interior de uma cultura (KLINGER, 2012, p. 29).

O fato é que, como leitores, nunca fomos tão invocados pela literatura, com tanta frequência e intensidade, como hoje o temos sido. Os narradores hesitantes e as personagens perdidas dirigem-se à consciência do leitor, esperando seu reconhecimento, sua afiliação e cumplicidade emocional ou estética, para que sua existência seja legitimada. A narrativa brasileira contemporânea vive um momento muito interessante, pois parece empenhada em discutir a si própria, evocando, ainda o discurso da metaficção - cujo movimento é o mesmo: para si. 
Integrada à crescente onda de "romances do eu", a autofição é uma forma de expressão híbrida, que mescla ficção e autobiografia. $\mathrm{O}$ termo foi cunhado pelo francês Serge Doubrovsky, em 1977, no prefácio de seu livro Fils. É importante, no entanto, entendermos que as definições primárias de Doubrovsky sofreram mudanças e foram atualizadas por novos estudos, de modo que hoje aquele tipo de autoficção é tomado como um exemplo do gênero encontrado entre diversos outros.

Em função disso, Klinger (2012) coloca a autoficção como uma categoria controvertida, que se elabora ao mesmo tempo em que acontece, surgindo num contexto artístico, entre os anos 70 e 80, denominado por Philippe Forest como "ego-literatura". Ela reconhece que o gênero se instaura no centro do paradoxo contemporâneo, no entremeio dos desejos narcisísticos e da impossibilidade de estabelecer um conceito de verdade através da escrita. Para Klinger, no entanto, "a categoria de autoficção é um conceito capaz de dar conta do retorno do autor depois da crítica filosófica da noção de sujeito" (2012, p. 23). O sujeito da autoficção, que está às voltas em busca de si mesmo, não apenas reflete o seu inconsciente na escrita, como também, através do texto literário, constrói imagens coletivas, revelando neuroses da sociedade contemporânea (FAEDRICH, 2014).

Diante do individualismo e do hedonismo produzidos pela lógica de sedução midiática, Gilles Lipovetsky (2004) propõe certo avanço no pensamento sobre a sociedade contemporânea ao afirmar que a modernidade ainda não foi totalmente superada, já que não estaríamos vivendo a pós-modernidade, mas uma terceira fase da modernidade: a hipermodernidade: "Hipercapitalismo, hiperclasse, hiperpotência, hiperterrorismo, hiperindividualismo, hipermercado, hipertexto - o que mais não é hiper? $\mathrm{O}$ que mais não expõe uma modernidade elevada à potência superlativa?" (LIPOVETSKY, 2004, p. 53). Para ele, o mérito do neologismo "pós-moderno" concentrava-se em apontar uma reorganização social e cultural, uma mudança no sentido rumo ao qual nos dirigíamos enquanto sociedade, diferentemente daquela direção que antes seguíamos. A pós-modernidade, para Lipovetsky, é um estágio de transição - um breve momento que já não está centrada na potencialização e na intensificação da experiência humana, de forma que em nossos dias é possível perceber a dimensão exponencial incorporada na prática da vida social:

Cada domínio apresenta uma vertente excrescente, desmesurada, "sem limites". Prova disso é a tecnologia e suas transformações vertiginosas nos referenciais sobre a morte, a alimentação ou a procriação. Mostram-no também as imagens do corpo no hiperrealismo pornô; a televisão e seus espetáculos que encenam a transparência total [...] Para lutar contra o terrorismo e a criminalidade, nas ruas, nos shopping centers, nos transportes coletivos, nas empresas, já se instalam milhões de câmeras, meios eletrônicos de vigilância e identificação dos cidadãos: substituindo-se à antiga sociedade disciplinar-totalitária, a sociedade da hipervigilância está a postos (LIPOVETSKY, 2004, p. 55).

O hipernarcisismo, para Lipovetsky (2005), é um novo estágio do individualismo, pois inaugura o surgimento de um perfil inédito do indivíduo nas suas relações consigo mesmo, com seu corpo, com os outros, com o mundo e com o tempo, introduzindo, assim, uma nova fase nas relações sociais. O famoso selfie, um exemplo emblemático que chegou ao ponto de produzir a demanda de um instrumento específico para sua execução, o selfie stick, tornou-se uma fonte de retratos do Eu que visam a um grande número de likes, comentários e compartilhamentos do sujeito, assegurando seu caráter narcisístico e de promoção do indivíduo. Esse sujeito contemporâneo pratica o culto do "presenteísmo", em que o predomínio do "aqui-agora" leva-o a viver intensamente todas as possibilidades oferecidas pelo momento, fazendo com que ele se debruce constantemente sobre o presente, na tentativa de protegê-lo, reciclá-lo e arrumá-lo. A consagração do presente surge, justamente, da revolução do cotidiano, que estimula os novos modelos de vida e canaliza todas as paixões nesta instância temporal. "Instala-se o 'narcisismo coletivo', sintoma social da crise generalizada das sociedades burguesas, incapazes de enfrentar o futuro de outro modo, a não ser com desespero" (LIPOVETSKY, 2005, p. 33). Assim, a compressão do tempo, a brevidade e a lógica urgentista instauram na sociedade as marcas da insegurança e do pânico.

Desse modo, a exigência de uma flexibilidade contínua desafia o sujeito a construir uma identidade que não seja firme ou fixa, mas que seja capaz de transparecer aos outros um pouco de responsabilidade e coesão. Bauman (1998) afirma que a peça essencial desse jogo é a mobilidade, de modo que o indivíduo possa deslocar sua identidade quando as circunstâncias exigirem. De qualquer forma, o autor entende que nenhum ser humano pode afirmar com total segurança sua permanência em um determinado lugar, afinal, independentemente de onde estivermos, sempre nos sentiremos, ao menos em parte, deslocados.

Dalcastagnè (2012) também destaca o presenteísmo como um sentido recriado do presente que muitas vezes não passa de um embuste. Para a autora, "a possibilidade de narrar o passado parece estar estreitamente ligada à ideia de ser autor - e não apenas um autor - dele" (DALCASTAGNÈ, 2012, p. 81). Para esse autor, a narrativa assume o poder de dar sentido ao que não tem, pois, quando ele se reconhece como um filtro para as 
outras narrativas, assume que ao narrar um personagem é de si que ele narra, de modo que o passado retratado pela história da personagem desemboque, inevitavelmente, no seu presente.

Temos aí uma sequência de "biografias" que falam do passado sem nunca tirar os olhos do presente. É esse, basicamente, o tempo dessas narrativas, porque é o tempo dessas personagens, todas entre a juventude e a maturidade - são os velhos que costumam ser representados vivendo no passado, ou as crianças que são revisitadas pelo olhar do futuro. Essa redução dos horizontes temporais, que leva a 'um ponto em que só existe o presente', nas palavras de David Harvey, encontra expressão em Teatro, de Bernardo de Carvalho, mas também em As mulheres de Tijucopapo, de Marilene Felinto (DALCASTAGNÈ, 2012, p. 89).

O romanesco seria essa tentativa de tornar coerente esse presente fragmentado, pela escuta de si mesmo diante do espelho que se toma como um outro: "Enquanto se fala (ou se escreve), diriam Julianos, Totonhins, Rísias e tantos narradores sem nome, pressupõe-se a presença - por remota que seja - de alguém que ouve (ou lê). É ele (ela) quem confirma minha existência" (DALCASTAGNÈ, 2012, p. 92). Por essa razão, para Dalcastagnè, por mais que estejam mergulhadas no passado, as narrativas em primeira pessoa não poderiam situar-se em outro tempo que não o presente: "nossa existência precisa ser confirmada aqui e agora, todos os dias" (2012, p. 92). Em Divórcio, Ricardo Lísias confirma muito bem esse conceito ao utilizar a metáfora da perda de sua pele após o episódio traumático da separação. Nas primeiras linhas do romance, o narrador afirma: "Depois de quatro dias sem dormir, achei que tivesse morrido" (pos. 41 de 2801)2. E mais adiante:

No sexto dia, com o corpo sem pele queimando apesar do frio, não me senti morto: tive certeza de ter enlouquecido. Eu acabara de escrever um SMS chamando minha ex-mulher de puta quando, na metade de uma frase autobiográfica, achei que estava vivendo um de meus contos.

Com certeza eu assinaria essa história. [...]

Será que tudo não passa de um conto que estou escrevendo? (pos.150)

É nesse contexto presenteísta e evasivo que se desenvolve a figura do Narciso contemporâneo, que também é caracterizado pela abolição do trágico, ocasionando uma forma inédita de apatia e de profunda indiferença em relação ao mundo que nos cerca. Isso explica, em parte, a abundância de informações às quais

\footnotetext{
2 Apontamos "Pos" como a posição do ebook.
}

somos expostos diariamente e a fugacidade com que os acontecimentos noticiados pela mídia se substituem, impedindo que uma emoção duradoura parasite o indivíduo, como nos mostra Lipovetsky:

\begin{abstract}
$\mathrm{Na}$ verdade, o narcisismo foi gerado pela deserção generalizada dos valores e finalidades sociais, ocasionada pelo processo de personalização. A anulação dos grandes sistemas de sentidos e o hiperinvestimento no Eu andam de braços dados: nos sistemas com 'aparência humana', que funcionam para o prazer, o bem-estar, a despadronização, ou seja, psicológico, desembaraçado dos enquadramentos de massa e projetado para a valorização geral do indivíduo. [...]. O narcisismo é o efeito do cruzamento entre uma lógica social individualista hedonista, impulsionada pelo universo dos objetos e dos sinais, e uma lógica terapêutica e psicológica, elaborada desde o século XIX a partir da aproximação psicopatológica (2005, p. 34 e 35$)$.
\end{abstract}

Dessa forma, Lipovetsky (2005) compreende o narcisismo não apenas como uma paixão pelo conhecimento de si mesmo, mas também como uma paixão da publicização íntima do $\mathrm{Eu}$, que ele diz podermos comprovar através da enxurrada de biografias e autobiografias que têm sido publicadas. Arriscamo-nos, aqui, a comprovar essa lógica publicitária do sujeito também através das mídias sociais, uma vez que Sébastien Charles (2009) afirma que uma das manifestações da lógica excessiva da hipermodernidade é a mercantilização desenfreada não apenas das coisas, mas também dos seres. O hiperconsumo, nesse sentido, é revelado pelo autor como "um consumo de bens materiais que absorve e integra partes cada vez maiores da vida social e que conduz a pensar todas as relações sob a forma de relações mercantis e a analisar qualquer relação social sob a forma de uma relação de produção e de consumo" (CHARLES, 2009, p. 130).

A obra de Lísias ilustra bem essa lógica à medida que seu autor utiliza suas redes sociais como prateleiras onde se oferece como um personagem, especialmente no Facebook, onde todas as polêmicas que circunscrevem seus romances são publicizadas, muitas vezes em caixa alta e com chamadas características de manchetes de jornal: "SOMOS BEST SELLER!"; "E O ROMANCE 'DIVÓRCIO' CONTINUA!"; "NÃO DESISTAM DE MIM!"; "NO UOL. TODO MUNDO CONTINUA PASMO!"; "PRINCIPAL SITE DE NOTÍCIAS JURÍDICAS FALA DO 'DELEGADO TOBIAS'" (FACEBOOK. Ricardo Lísias, 2015). Para Charles (2009), no universo contemporâneo o sujeito não se satisfaz mais apenas em viver o presente, é necessário verbalizá-lo e, mais do que isso, mostrar como se 
o vive bem. A relação com a arte muitas vezes não é diferente:

A expressão de si mediatizada tornou-se um dos fantasmas dos nossos artistas contemporâneos, que não desejam mais ser admirados e permanecer desconhecidos, como sonhavam os poetas românticos, simplesmente porque eles sabem que ser conhecidos tornou-se um estágio obrigatório para o sucesso (CHARLES, 2009, p. 139).

A contemporaneidade faz surgir uma zona extremamente propícia para a simulação, uma vez que vivemos o advento das redes sociais e da comunicação virtual, quando as novas tecnologias facilitam essa espécie de criação. Assim, o sujeito encontra cada vez mais possibilidades de representar uma identidade falsa ou recriar sua identidade com o propósito de forjar uma realidade que não condiz com aquela que habita - e sobre a qual não tem agenciamento se não na esfera virtual. Isso se torna ainda mais confuso à medida que o ciberespaço cresce e os indivíduos assumem um grande contingente de papéis e máscaras. "O que é 'realidade', se ela é capaz de tanta simulação?” (DOUGLAS KELLNER, 2001, Apud FELINTO E SANTAELLA, 2012, p.33).

Essas tendências contemporâneas sociais e comportamentais também são, evidentemente, observadas pelos profissionais da comunicação, especialmente os publicitários, que se mostram sempre muito interessados em adequar suas estratégias às demandas da sociedade. Essa subjetividade sugere uma cumplicidade com o público, uma vez que nem tudo está explícito e lacunas propositais são criadas, a serem preenchidas pelo leitor. Esse receptor assume o papel de cúmplice e parceiro no jogo da interlocução, uma vez que é responsável pela contextualização da mensagem, atribuindo coerência aos enunciados. Ao analisar o texto publicitário, Elizabeth Moraes Gonçalves (2006, p. 18) afirma que ele "não é um texto que se desenvolve na linearidade - grande parte do significado a ser apreendido fica na leitura das entrelinhas ou da situação que o envolve”. Para Jorge Martins (1997, p.40), "mais do que a significação explícita, o que conta no texto publicitário é o que está subjacente, implícito, o que é conotado". O narrador, à medida que constrói esses espaços, supõe um interlocutor que detém o repertório necessário para completar o sentido. Esse narrador contemporâneo já não limita suas narrativas ao ambiente literário tradicional, tampouco depende de estruturas específicas ou da mídia impressa. Ele ultrapassa o limite do livro, do e-book e dos diversos suportes de leitura conhecidos para fazer ecoar sua voz nas redes sociais, onde a diegese tem continuidade.

Esse contexto também se apresenta como um reflexo do momento que vivemos, quando os sistemas de produção, distribuição e consumo são condicionados e reorganizados por uma série de procedimentos de natureza estética. Lipovetsky (2014) contextualiza esse fenômeno de estetização a partir do avanço de uma cultura de globalização capitalista. Na Antiguidade, a Estética apresentava um caráter mais ritualístico, vinculado à mística religiosa como uma forma de expressão. Com a ascensão da aristocracia, estabelece-se uma distinção entre o artesão e o artista, e uma nova fase estética surge, quando este concentra seus esforços em bem servir e agradar ao público elitizado. A arte então rompe os vínculos até então estabelecidos com os mitos religiosos, consolidando um processo de secularização. A fase da estetização moderna, por sua vez, promove a complexificação da esfera artística, quando ela é emancipada da Igreja, passando a reconhecer-se a partir de critérios específicos de legitimidade e valor. Nesta fase criam-se dois universos antagônicos: um vanguardista e purista, e outro mais preocupado com o valor comercial da arte e o lucro (LIPOVETSKY, 2014).

Esse momento estético que vivemos hoje seria um processo de "hiperarte": "depois da arte-para-os-deuses, da arte-para-os-príncipes, e da arte-pela-arte, estamos agora na arte-para-o-mercado que triunfa" (LIPOVETSKY, 2014, p.32). A sensibilidade e os afetos veiculados pela indústria de consumo através do design, da moda, da publicidade, do cinema, etc., seduzem o indivíduo através da construção de um universo estético híbrido que alcança todos os estilos. Estamos, portanto, inseridos em um mundo fortemente marcado pela abundância e pelo ecletismo estético. Diante dessa realidade, Lipovetsky observa o cruzamento entre a sociedade do espetáculo e o imperativo comercial, que resulta em um fenômeno nomeado pelo autor como "transestético", "onde se misturam design e star system, criação e entertainment, cultura e show business, arte e comunicação, vanguarda e moda" (LIPOVETSKY, 2014, p. 33). Trata-se de uma hipercultura que promove não a separação, mas o cruzamento dos diferentes gêneros: "O antigo reino do espetáculo desapareceu; foi substituído pelo do hiperespetáculo que consagra a cultura democrática e comercial do divertimento" (LIPOVETSKY, 2014, p. 33).

É através da "estrelização", por exemplo, dos chefs cozinheiros e designers, que o capitalismo favoreceu o desenvolvimento de um indivíduo estético ou, como prefere Lipovetsky (2014), transestético. Isso porque esse sujeito já não se limita a um esteticismo antigo ou tradicional, compartimentado e hierarquizado, pois está inserido em uma cultura democrática e heterogênea. Lipovetsky (2014) caracteriza esse indivíduo transestético como um ser reflexivo, eclético e nômade - instável, acrescentaríamos, porque dependente dos movimentos da "moda". Trata-se de alguém ao mesmo tempo exigente, 
consumista, deslumbrado com o descartável, com as celebridades e com o divertimento fácil, que assume "uma atitude estética para com a vida" (LIPOVETSKY, 2014, p. 37).

Esse sujeito transestético é personagem-narradorautor dos romances de Lísias, um sujeito preocupado com sua própria figuração ficcional, voltado a si mesmo como um objeto cujo exercício de criação evoca essa atitude estética. Esse exercício pode ser apenas aquele de parecer ser o que a sociedade espera que sejamos em cada uma das situações, como em $O$ céu dos suicidas, romance de 2012. Nele, o narrador-protagonista, Ricardo Lísias, narra a experiência traumática vivida a partir do suicídio de seu amigo André. A história se desenvolve a partir do abalo causado pela morte desse grande amigo do narrador, revelando os sentimentos de culpa e remorso que corroem e repercutem no desequilíbrio que toma conta de Ricardo a partir dessa perda. Esse narrador, que é um especialista em coleções e, na verdade, não coleciona nada, se empenha em provar que, ao contrário do que muitas doutrinas religiosas afirmam, os suicidas também são dignos do céu. Nessa busca por explicações e justificativas para seus conflitos interiores, ele tenta retomar o trabalho como consultor de colecionadores, mas acaba sendo agressivo com todos aqueles que procuram seus serviços. Ele visita o último lugar em que o melhor amigo esteve internado antes de cometer suicídio e passa a contar, paralelamente aos relatos de suas experiências pessoais, diferentes histórias envolvendo diferentes personagens daquele espaço. Na sequência, faz uma viagem ao Líbano na busca de explicações para um suposto envolvimento do seu tio-avô com o terrorismo que, na verdade, não passa de uma obsessão sem fundamento algum. Nessa viagem, um senhor idoso o coloca de joelhos em uma igreja, e o gesto o conforta, tornando-se outra obsessão nos momentos de crise - como que um gestual estético de superação, visto que isento de fé.

É possível identificar no Ricardo Lísias que narra a história traços de instabilidade característicos do narrador de autoficção, condição que, como vimos anteriormente, também reflete a personalidade do indivíduo hipermoderno. A morte do melhor amigo e o peso da culpa, por tê-lo expulsado de sua casa poucos dias antes que ele cometesse suicídio, provocam um transtorno e uma irritabilidade intolerante no narrador, desencadeando um comportamento impulsivo, ambíguo e hostil, que faz com que ele seja extremamente grosseiro e agressivo com as pessoas que se aproximam para, em seguida, arrependerse disso. Essa hostilidade também representa muito bem a escrita nas redes sociais e o comportamento hodierno em geral. Ao longo da narrativa é possível identificar uma série de episódios em que esse comportamento confuso se repete: o narrador se desculpa pelas ofensas lançadas e logo depois volta a agredir o objeto de suas grosserias. Há uma passagem, por exemplo, em que Ricardo está obstinado em descobrir a razão pela qual seu tio-avô trocou uma série de cartas com destinatários residentes em países árabes. Desconfiado de que o sujeito tivesse um envolvimento com o terrorismo na década de 1970 e 1980, ele procura uma tia que passa o tempo desenhando árvores genealógicas. A mulher se mostra nervosa e o repreende quando ele toca no assunto: "A velhota fechou a cara e, nervosa, disse que não é porque meu amigo se matou que posso incomodar a memória dos que se foram pela vontade de Deus" (LÍSIAS, 2013, pos. 317). Não demora muito para que, ao sentir-se contrariado e repreendido, o narrador comece a despejar sua agressividade na mulher: "Então vai tomar no cu, sua filha da puta. Cuspi na cara dela mas, com o grito, a desgraçada se afastou e acabei atingindo a tal árvore genealógica" (LÍSIAS, 2013, pos. 325). Alguns capítulos depois, o narrador se arrepende e decide se desculpar: "Vou pedir desculpas para a minha tia" (LÍSIAS, 2013, pos. 385). Mas, logo adiante, volta a agredi-la com palavras outra vez.

As narrativas de Lísias, no entanto, não se restringem ao universo literário. Como exímio intérprete do indivíduo contemporâneo hipernarcisista e como sujeito imerso no ciberespaço, o escritor tem o hábito de divulgar seu trabalho através de seu perfil pessoal no Facebook. A publicização de Lísias começa tímida em $O$ céu dos suicidas. Em seu perfil, o escritor anuncia o lançamento do livro e os textos verbais, com títulos em caixa alta, assemelham-se a chamadas publicitárias. Em uma das publicações do autor em seu perfil no Facebook, cuja configuração de privacidade é pública, ou seja, visível a qualquer usuário da rede social, o texto que compõe a legenda da imagem de capa do livro é contraditório em um primeiro momento, justamente para despertar a curiosidade do leitor: "APELO: NÃO COMPREM MEU LIVRO!” (FACEBOOK. Ricardo Lísias, 2012). Em seguida é possível compreender, pelo texto que segue, que a publicação de abril de 2012 é, na verdade, um convite para o lançamento do livro onde ele também será comercializado.

A publicação de Lísias apresenta dois elementos básicos de uso comum na criação de um anúncio publicitário: título, imagem e texto de apoio. Além disso, não é somente na estrutura que o texto do escritor revela o apelo publicitário, mas também no conteúdo, uma vez que o título manifesta o desejo de atrair a atenção do leitor de forma irônica, despertando seu interesse e conquistando sua atenção a fim de que ele não desista da leitura e chegue até o texto de apoio, onde será atingido pela mensagem principal e concretizará o sentido pretendido pela publicação. A imagem da capa do livro que também integra essa postagem parece servir, uma vez 
mais, como forma de atrair o leitor, pois há algum tempo as pesquisas ${ }^{3}$ já revelam que os usuários do Facebook se interessam muito mais por textos imagéticos, que geram mais interação e engajamento, do que verbais.

$\mathrm{O}$ envolvimento com o leitor e a expectativa de engajamento também aparecem em uma publicação em agosto de 2013, quando a imagem da capa do livro aparece acompanhada de uma longa legenda. $\mathrm{O}$ texto inicia com a típica chamada em caixa alta e um apelo: "TOPAM TORCER POR MIM??" (FACEBOOK. Ricardo Lísias, 2013). A seguir, o escritor explica no texto da legenda que O céu dos suicidas está entre os dez finalistas do prêmio Bourbon Zaffari de Literatura de Língua Portuguesa. Mas a essa altura, em agosto de 2013, todos os olhares já estavam voltados para o lançamento mais recente e polêmico de Lísias: Divórcio.

A narrativa de Divórcio gira em torno do trauma ocasionado pela separação do narrador-protagonista - que, da mesma forma que na obra analisada anteriormente, leva o mesmo nome do autor - e de sua esposa, uma jornalista que escreve todas as noites em um diário logo depois que o marido adormece. Ricardo encontra esse diário, o lê e se revolta contra o modo depreciativo como a esposa o descreve nesses registros onde, inclusive, confessa tê-lo traído com um cineasta famoso durante a cobertura do Festival de Cannes de 2011. A corrida e a literatura são os meios que o protagonista encontra para se recuperar da dor da separação que o faz sentir-se em carne viva, sem pele. Ao longo da narrativa são inseridos trechos do suposto diário e também fotografias pessoais do escritor, de sua infância e família em preto e branco. ${ }^{4}$

Nesse sentido, percebemos que o romance Divórcio, de forma um pouco mais evidente ainda do que $O$ céu dos suicidas, conversa de perto com as características que definem a sociedade hipermoderna contemporânea. A identidade de Lísias é fluida e moldável tanto na ficção quanto naquilo que se acessa do sujeito que também se constrói nas redes sociais. A inconstância entre a voz de um narrador que, ora é autodiegético, ora exterioriza a consciência sobre a ficção, permeia a obra e se divide em momentos em que ele afirma ter vivido, de fato, tudo

\footnotetext{
3 Uma pesquisa revelou que publicações com fotografias geram até $120 \%$ mais engajamento do que outros tipos de publicações no Facebook. Disponível em: <http://www.ragan.com/Main/Articles/Infographic Photo_posts_get_120_more_engagement_on_46290.aspx>.Acesso em: novembro.2015.

4 Em entrevista, o autor confirma que as fotografias fazem parte de seu acervo pessoal quando diz: "Na verdade, as fotografias, pra mim, serviam um pouco pra aumentar essa questão de colocar a verossimilhança sempre em jogo. Mas eu queria dizer uma coisa curiosa: muitos dos aspectos autobiográficos do romance não são autobiográficos, é uma vida minha realmente inventada. Evidentemente que as fotos são verdadeiras, mas as histórias daquelas fotos é uma história manipulada" (LÍSIAS, 2015) Disponível em: <http://www.cafecolombo.com.br/ideias/entrevistaricardo-lisias-fala-sobre-o-polemico-romance-divorcio $>$. Acesso em: dez..2015.
}

o que descreve na narrativa, assumindo uma posição para além daquele universo diegético: "Acabo de achar a folha com as frases autobiográficas que redigi naquele dia. Um pouco abaixo do meio, depois do comentário sobre o enterro da minha avó, escrevi várias vezes com caneta vermelha: ACONTECEU NÃO É FICÇÃO" (LÍSIAS, 2013, pos. 153 e 161), fazendo surgir do narrador autodiegético o escritor que o desenha. Já em outros fragmentos esse narrador-escritor assegura que é tudo ficção: "Não aconteceu nada: ela não escreveu esse diário e não cobriu o Festival de Cannes de 2011 para um jornal. É só um conto" (LÍSIAS, 2013, pos. 153). Não há nenhum vestígio de solidez ou concretude na narrativa de Divórcio, o narrador parece estar constantemente fora de juízo, e o delírio de estar vivendo a ficção ou ficcionalizando a realidade é a única constante nessa narrativa: "Só pode ser ficção" (LÍSIAS, 2013, pos. 153); "Aliás, não há uma palavra de ficção nesse romance" (LÍSIAS, 2013, pos. 2034).

A estética de $O$ céu dos suicidas parece ser um ensaio do que vai ser potencializado em escala muito maior neste romance. As relações exacerbadas com o corpo, outra característica que identifica o sujeito hipermoderno, são mostradas em todo o romance, especialmente através da metáfora da pele, que o narrador sente desprendida do corpo no momento em que descobre o que sua ex-mulher escondia: "O que deixou meu corpo morto, no entanto, não foi nada disso. A seguinte frase tirou-me toda a pele: Casei com um homem que não viveu. O Ricardo ficou trancado dentro de um quarto lendo a vida toda" (LÍSIAS, 2013, pos. 1471).

O desprezo com que a esposa o retrata no diário aliado à dor da traição e ao consequente reconhecimento do fracasso nesse relacionamento levam o narrador a sentir uma dor tão grande e intraduzível que ele precisa usar uma metáfora para que o leitor não a imagine menor do que a dor de uma pessoa que teve toda a sua pele arrancada e agora se encontra em carne viva: "Um corpo sem pele é muito sensível. O calor aumenta a impressão de queimado, e o frio, por sua vez, parece que vai direto para os ossos" (LÍSIAS, 2013, pos. 689); "Como meu corpo não tinha pele, eu passava o tempo inteiro conferindo meus ossos e os órgãos mais importantes" (LÍSIAS, 2013, pos. 932). Esse simbolismo da perda de pele é uma das representações mais admiráveis da narrativa, pois é com a pele que sentimos e sem ela, portanto, é como se o narrador não fosse capaz de sentir. É a representação de uma morte em vida. Ao mesmo tempo, a ausência dessa camada do corpo faz com que ele se sinta exposto, mas tão intimamente exposto que seus órgãos internos se tonam visíveis.

A publicização do romance inicia na própria narrativa, em que o narrador afirma a possibilidade 
sustentada pela obra: "Não sei quantas pessoas vão ler Divórcio. Provavelmente, um pouco mais do que meus outros livros. Alguns vão gostar tanto que, no mesmo dia, acabarão procurando $O$ céu dos suicidas" (LÍSIAS, 2013, pos. 2597). E a previsão do narrador se cumpre na vida do autor em 4 de agosto de 2015, como mostra Lísias, ao compartilhar no Facebook a publicação de uma leitora surpreendida pela previsão do comportamento dos leitores, pois, ao finalizar a leitura de Divórcio, ela já está ansiosa pela leitura de $O$ céu dos suicidas.

Além disso, diversas vezes o autor divulga postagens em que ele e Divórcio são mencionados, sempre de forma positiva, como todo texto publicitário deve ser. Em 24 de agosto de 2015, Lísias compartilha uma imagem de um fragmento do romance no Kindle, publicada por uma leitora que agradecia a ele por ter escrito o livro. No título, em caixa alta, o autor anuncia: "DA SÉRIE 'NUNCA VÃO PARAR DE LER ESSE LIVRO'!!!" (FACEBOOK. Ricardo Lísias, 2015). O autor comunica que, mesmo que o livro tenha sido lançado há mais de dois anos, ele continua atual e atuante na vida de seus leitores e, portanto, vale a pena consumi-lo. Ele provoca o leitor a consumir sua obra ao mesmo tempo em que declara sua imortalidade.

A situação do e-book Delegado Tobias é um pouco diferente dos romances analisados até aqui. $\mathrm{O}$ folhetim virtual - lançado pelo selo "Formas Breves", editado pela e-galáxia e distribuído exclusivamente em formato digital - é narrado em terceira pessoa, por um narrador com ares de jornalista e com uma linguagem própria de imprensa. A narrativa, lançada em cinco partes, retrata o inquérito que investiga a morte de um escritor chamado Ricardo Lísias, da qual o principal suspeito é um sujeito que leva o mesmo nome da vítima. O caso é investigado por um delegado de polícia chamado Paulo Tobias, e a narrativa é atravessada por diálogos descontextualizados, documentos judiciais e recortes de títulos de matérias jornalísticas que abordam o caso de forma sarcástica ou debochada.

O mais interessante, no entanto, é que a narrativa de Delegado Tobias foi construída simultaneamente nas redes sociais - especialmente no perfil pessoal de Ricardo Lísias no Facebook - e no e-folhetim oferecido de modo fragmentado ao leitor. Aliás, a história iniciou-se no próprio Facebook, no dia 4 de setembro de 2014, três dias antes do lançamento da primeira parte do e-book, quando o autor publicou uma imagem que simulava um recorte de jornal com uma informação incompleta contendo seu nome.

Nos dias seguintes que precederam o lançamento, outras imagens semelhantes foram publicadas pelo autor em seu perfil. Os títulos de matérias ficcionais eram postados sempre sozinhos, sem qualquer legenda ou explicação. Os recortes que anunciavam o caso narrado no e-book foram utilizados como um teaser do folhetim. A estratégia de provocar a curiosidade do leitor foi eficaz e gerou especulação e alguns comentários nas redes sociais de Lísias. O resultado da tática de publicização foi extremamente positivo e, um dia antes do lançamento da primeira parte do e-folhetim, o autor publicou a imagem de capa em seu perfil no Facebook anunciando que, mesmo antes do lançamento oficial, Delegado Tobias já era best-seller. A legenda da imagem conserva as características já observadas nas publicações anteriores do autor, seduzindo pelo título provocante: "NEM SAIU E JÁ É BESTSELLER" (FACEBOOK. Ricardo Lísias, 2014). E, nesse caso, o texto que acompanha a fotografia também carrega o tom sarcástico que vamos encontrar na narrativa que ele publiciza. A estratégia parece uma via de mão dupla, que alcança tanto o público que identifica o riso do autor ao classificar sua obra como best-seller, quanto aqueles que serão atraídos justamente pelo sentido literal da expressão.

A primeira parte do e-folhetim, onde está concentrada a maior parcela do texto verbal que compõe a obra, inicia com a primeira imagem publicada como teaser no perfil de Ricardo Lísias. As partes 2 e 3 da narrativa, distribuídas semanalmente, mesclam o texto verbal com imagens de documentos do suposto inquérito retratado na obra, e-mails, diálogos em redes sociais e recortes de matérias jornalísticas que também são publicadas no perfil do Facebook do autor. A parte 4 é composta por um documento com algumas páginas em branco, onde as únicas informações disponíveis são as que compõem a ficha catalográfica. Finalmente, a parte 5 compila todas as publicações feitas nas redes sociais e uma breve explicação acerca da construção da narrativa de Delegado Tobias.

A história é extremamente fragmentada, inconclusa e confusa. Alguns recursos estéticos usados anteriormente de forma moderada são maximizados nessa obra, e esse parece ser o objetivo de Lísias ao construir esse e-book. Ele brinca, satiriza e ironiza o tempo inteiro o conceito de autoficção, a mídia, os jornalistas e todo aquele grupo social que ele critica e denuncia em seus romances. Muitas páginas do folhetim são encerradas com frases pela metade, que terminam sem concretizar um sentido, sem pontuação e sem continuação: "Também segundo o delegado Tobias, talvez nos próximos dias um crítico literário seja também convida-" (LÍSIAS, 2014, pos. 27); "Como o nome já estava registrado, o assassino não encontrou” (LÍSIAS, 2015, pos. 41); “A família de Lísias não retornou nenhuma" (LÍSIAS, 2014, pos. 60). Essa estratégia fez com que os leitores mais desavisados imaginassem que suas edições de Delegado Tobias estivessem com algum defeito.

Paralelamente à narrativa, surge no Facebook o perfil 
de um sujeito que leva o mesmo nome da personagem que dá nome ao e-book, Delegado Tobias. Ali, ele começa a reivindicar sua existência e passa a interagir com o perfil de Ricardo Lísias. No dia 8 de setembro de 2014, Lísias publica a imagem de um e-mail recebido, endereçado a ele e ao editor do folhetim, assinado por um delegado de polícia chamado Paulo Tobias, que ameaça processá-los por utilizarem seu nome em uma obra de ficção, afirmando que o "público médio" não saberia diferenciar o que é ou não ficção. No dia seguinte, Lísias publica a imagem de capa de Delegado Tobias, acompanhada de um texto onde ele afirma que esse indivíduo alega ser uma personagem de seu e-book e está movendo uma ação judicial para tirar seu folhetim de circulação, o "leitor médio" aparece novamente no texto, ironizando aquele leitor de sua obra que não entende o jogo que ele propõe.

Lísias não deixa passar nenhuma oportunidade de reforçar esse jogo e, no dia 10 de setembro de 2014, o autor publica em seu perfil outro recorte de jornal, dessa vez para anunciar o recurso judicial de que lançaram mão seus advogados, no suposto processo em que o delegado Tobias tentava proibir a circulação de seu e-book. O título da legenda que acompanha a imagem anuncia boas notícias acerca de Delegado Tobias, mas, no texto de apoio, depois de anunciar o uso de um novo instrumento judicial para garantir a continuidade de seu folhetim, o autor revela: "mas a notícia é outra". A frase final da legenda remete à imagem do falso título da matéria jornalística, onde a sátira continua no anúncio de que, depois de proibido, o e-book é vendido para o cinema, onde Lísias garante que será assassinado. Um dos comentários nessa publicação afirma aquilo que todo o leitor atento de Lísias já desconfiava: "cara se não fosse escritor vc poderia ser publicitário, na boa!” (FACEBOOK. Ricardo Lísias, 2014).

Podemos dizer, assim, que as três obras analisadas inovam esteticamente, especialmente os romances, mostrando-se como janelas escancaradas para esses tempos hipermidiáticos. Como conjunto, elas revelam, se não certa evolução no "projeto literário" de Lísias, a adoção de estratégias bem definidas para colocar em prática aquilo que já se apresenta como um estilo do autor, pois aqueles elementos que parecem ter funcionado de modo acertado em uma obra são, geralmente, potencializados na narrativa seguinte.

O céu dos suicidas é a obra que insere Ricardo Lísias na estética autoficcional. Através dela, o autor parece fazer questão de se mostrar "do seu tempo", como se isso caracterizasse a sua própria escrita como algo novo, no desejo de sinalizar a construção de seu projeto literário. E ele coloca no narrador essa missão, tornando-a metalinguística, como que uma função da literatura. O mapeamento das relações que se constituem no mundo contemporâneo também se destaca na obra, especialmente no que diz respeito ao paralelo traçado pelo autor no encadeamento das relações virtuais e face a face, onde é possível identificar uma pretensão de prever as consequências de um comportamento agressivo constante na internet, que de tão exacerbado resultaria em reflexos na vida real.

A publicização, nesta obra, também começa de forma tímida, ainda que a intenção das publicações do autor nas redes sociais seja sempre evidente. $\mathrm{O}$ autor, o sujeito Ricardo Lísias que recebe os direitos autorais, não perde uma oportunidade de alfinetar as engrenagens do mundo que habita e que ferem as personas que ele cria à sua imagem e semelhança - e fazem-no sentir-se culpado ou sozinho ou incompreendido - e nem de publicizar seu romance ou seu papel como escritor.

Já em Divórcio percebemos todas essas características elevadas a uma potência maior. A obra manifesta com criatividade a representação narcisista do indivíduo contemporâneo ao retratar um evento tão complexo quanto uma separação, fruto de algo ainda mais complexo que é um relacionamento, narrado de forma unilateral, a partir de um único ponto de vista. É interessante observar que a frase estopim para a metáfora da perda de pele é uma sentença não sobre a relação do casal, mas sobre o próprio narrador, o que o atinge é justamente enxergar-se pelo olhar do outro, fazendo ecoar a ausência de alteridade típica do nosso tempo.

A publicização dessa vez também é muito mais forte. O autor se aproveita da polêmica que circunscreve a obra e, ao mesmo tempo em que critica as especulações acerca de sua vida, de seu casamento fracassado e de sua ex-mulher, utiliza-as como meio de tornar ainda mais conhecida a sua obra. Nesse sentido, as postagens que publicizam Divórcio no Facebook estão muito mais ligadas às polêmicas que giram em torno do romance, à velocidade com que ele some das prateleiras e esgota edições e ao seu caráter de denúncia em relação ao jornalismo praticado atualmente que autor tem prazer em criticar.

Delegado Tobias, narrativa inteiramente construída de forma a satirizar o rótulo autoficcional que é atribuído às obras de Lísias e com o qual ele evidentemente discorda, é a potencialização máxima dessa estética ambígua. A obra extrapola as fronteiras da autoficção e parece-nos mais uma mensagem encarregada de mostrar que o projeto literário do autor não cabe nesse rótulo que lhe é tão incômodo. Nesse jogo em que o protagonista da obra, homônimo do autor, é ao mesmo tempo morto e acusado de seu homicídio, ele parece evocar "A morte do autor", de Barthes (2004), como uma metáfora de que, se o autor já está morto, ele não deve ser confundido com a ficção - recado àquele "leitor médio". A publicização, nesse caso, foi a de maior escala, porque uma parte da narrativa também foi construída fora do e-book, nas 
publicações e interações de Ricardo Lísias em seu perfil no Facebook. Ali, ele brincou com a história da proibição de seu livro, simulando uma ação judicial movida por uma de suas personagens que alegava, através de um perfil falso criado pela editora, existir de verdade, fora da literatura.

Através da obra de Lísias, torna-se visível as possibilidades estéticas para a produção que emerge da hipermodernidade. $\mathrm{O}$ autor soube servir-se desses novos meios de dizer e redizer, mostrando-se um representante dessa geração de escritores da convergência. Além disso, aquele permanente temor sobre a perda de identidade do fenômeno literário a partir de sua integração ao mundo hipermidiático não se concretiza, pois seus romances reafirmam o gênero, demonstrando que o romance permanece como a epopeia desse nosso mundo abandonado pelos deuses - o espaço do sujeito frente ao seu próprio tempo. Ricardo Lísias, o escritor-autor, consegue ser esse sujeito que escreve e vende, o que é pontual atualmente.

Ainda que, evidentemente, outros escritores também utilizem ou já tenham utilizado a internet para publicizar suas obras, é difícil encontrar quem o tenha feito de forma tão criativa quanto Lísias, confundindo as diegeses, brincando com seus biografemas e ficcionalizando a si mesmo. As narrativas literárias e midiáticas do autor demonstram que a autoficção, como manifestação literária típica da sociedade contemporânea, pode se fazer instrumento de publicização do sujeito autor, principalmente quando aliada à escrita de redes sociais - espaço em que os sujeitos também têm-se constituído, em frente às telas, janelas escancaradas da hipermodernidade.

\section{Referências}

BAUMAN, Zygmunt. O mal-estar da pós-modernidade. Tradução de Mauro Gama e Cláudia Martinelli Gama. Rio de Janeiro: Zahar, 1998.

BARTHES, Roland. A câmara clara. Tradução de Júlio Castañon Guimarães. Rio de Janeiro: Nova Fronteira, 1984.

BARTHES, Roland. Roland Barthes por Roland Barthes. Tradução de Leyla Perrone-Moisés. São Paulo, Estação Liberdade, 2003.
BARTHES, Roland. Sade, Fourier, Loyola. Tradução de Maria de Santa Cruz. São Paulo: Martins Fontes, 2005.

CHARLES, Sébastien. Cartas sobre a hipermodernidade. Tradução de Xerxes Gusmão. São Paulo: Barcarolla, 2009.

DALCASTAGNÈ, Regina. Literatura brasileira contemporânea: um território contestado. Vinhedo: Horizonte, 2012.

FAEDRICH, Anna. Autoficções: do conceito teórico à prática na literatura brasileira. Tese (Programa de Pós-Graduação em Letras) - Pontifícia Universidade Católica do Rio Grande do Sul, Porto Alegre, 2014.

FELINTO, Erick; SANTAELLA, Lucia. O explorador de abismos: Vilém Flusser. São Paulo: Paulus, 2012.

FIGUEIREDO, Eurídice. Mulheres no espelho: autobiografia, ficção, autoficção. Rio de Janeiro: Eduerj, 2013.

GONÇALVES, Elizabeth Moraes. Propaganda \& Linguagem: análise e evolução. São Bernardo do Campo: Universidade Metodista de São Paulo, 2006.

GUMBRECHT, Hans U. História da literatura: fragmento de uma totalidade desaparecida. In: OLINTO, Heidrun K. (Org.). História de literatura - as novas teorias alemãs. Rio de Janeiro: Ática, 1996. p. 223-239.

KLINGER, Diana. Escritas de si, escritas do outro: o retorno do autor e a virada etnográfica. Rio de Janeiro: 7 Letras, 2012.

LIPOVETSKY, Gilles. A era do vazio: ensaios sobre o individualismo contemporâneo. Barueri: Manole, 2005.

LIPOVETSKY, Gilles. O capitalismo estético na era da globalização. Lisboa: Edições 70, 2014.

LIPOVETSKY, Gilles. Os tempos hipermodernos. São Paulo: Barcarolla, 2004.

LÍSIAS, Ricardo. Delegado Tobiase. São Paulo: E-Galáxia, 2014. [e-book], v. 1, 2, 3, 4, 5.

LÍSIAS, Ricardo. Divórcio. Rio de Janeiro: Objetiva, 2013.

LÍSIAS, Ricardo. O céu dos suicidas. Rio de Janeiro: Alfaguara, 2012.

LUKÁCS, George. A teoria do romance: um ensaio históricofilosófico sobre as formas da grande épica. Tradução de José Marcos Mariani de Macedo. São Paulo: Duas Cidades, 34, 2000

SANTAELLA, Lucia. Cultura das mídias. São Paulo: Experimento, 1996.

Recebido: 15 de abril de 2016.

Aprovado: 28 de agosto de 2016.

Contato: anamunari@terra.com.br taissicardoso@gmail.com 